\title{
DIGITAL DEVICE OVERUSE DURING THE COVID-19 PANDEMIC AND VISUAL IMPAIRMENT AMONG CHILDREN: IS THERE A RISK FOR LONG-TERM EFFECTS?
}

\author{
Detanac A. Dzenana \\ Department of ophthalmology, General hospital Novi Pazar, Serbia
}

Primljen/Received 25. 07. 2020. god.

Abstract: Global school closures and home quarantine caused by the COVID-19 pandemic increases digital screen time and the overall time spent on near work while decreasing outdoor time especially among school-going children, which can cause serious factors associated with asthenopia, refractive errors, low visual acuity, and accommodative insufficiency. Professionals believe that ophthalmologists now have an opportunity to draw attention to the problem, raise awareness among parents, children, and teachers, and eventually influence policymakers to develop strategies that will help children and students as well as parents and relevant institutions to deal with this issue even beyond the pandemic. Prompt implementation of adequate public and school policies and eye care services globally, effective planning of public health measures for prevention and treatment of myopia must be part of the crucial measures in the future. The consequences of widespread acceptance of digital devices in all spheres of public life by affecting visual function also affect learning, school performance, development of children, and thus their future.

Keywords: Covid-19, children, digital device overuse, visual impairment.

\section{INTRODUCTION}

We live in an era of digitalization and it is indisputable that digital technology is changing the world. Effects of digital device overuse on children's eyes and vision have become a significant subject of scientific research in the 21st century. During the COVID-19 pandemic, instituted lockdown measures which also included school closure has increased digital screen time. The COVID-19 pandemic opened a new chapter in this field of research which can be very useful in
Prihvaćen/Accepted 22. 08. 2021. god.

evaluating whether and how excessive digital device usage affects the vision in children. There are more and more studies investigating digital device use in the time of COVID-19 and its correlation with visual impairment (1-4). Also, many schools around the world have implemented digital devices and digital learning in their classrooms and this is only the phase of more radical usage of digitalization in the educational system. Therefore, it is also important to evaluate the results of current studies on the use of digital devices during the COVID-19 pandemic that can be of crucial importance for future vision and eye health in children and their development and learning. Professionals believe that ophthalmologists now have an opportunity to draw attention to the problem, raise awareness among parents, children, and teachers, and eventually influence policymakers to develop strategies that will help children and students as well as parents and relevant institutions to deal with this issue also beyond the pandemic.

\section{Visual implications of digital screen time, near work, and outdoor time before and during the COVID era}

Global school closures and in-house quarantine caused by the COVID-19 pandemic increases digital screen time and the overall time spent on near work while decreasing outdoor time especially among school-going children, which can cause serious factors associated with asthenopia, refractive errors, low visual acuity, and accommodative insufficiency.

Even before the COVID-19 pandemic, factors such as digital screen time, near work, and outdoor time and their impact on eye health have been the subject of many ophthalmology studies and professional 
meetings, specifically because of the ongoing myopia epidemic. Systematic research and meta-analysis performed by the Holden BA et al. and published in 2016, showed that the prevalence of myopia will increase from $30 \%$ now to $50 \%$ by 2050 , which means that around 5 billion people will be myopic by then and among them 1 billion with high myopia (5). Uncorrected refractive error was the second most common cause of blindness and the first most common cause of moderate to severe vision impairment globally in 2010 (6). Economic consequences are grave. It is estimated that the global cost of lost productivity due to uncorrected myopia was USD 244 billion and USD 6 billion due to myopic macular degeneration in 2015 (7). More important is the fact that high myopia is a risk factor for pathologic ocular changes such as retinal detachment, cataracts, glaucoma, myopic macular degeneration, all of which can cause irreversible vision loss (8).

It is a fact that ophthalmologists are facing an increased number of children complaining about symptoms associated with Computer Vision Syndrome (CVS) like eyestrain, headache, dry eyes, itching, and blurred vision due to excessive use of digital devices. There were only a few studies about the impact of digital device use on children's vision before the COVID-19 pandemic, but more and more new studies are investigating this issue since the pandemic began. Previous studies estimated that children can experience digital eyestrain (DES) that occurs in most cases because the visual demands of the task exceed the visual abilities of the individual to comfortably perform the task (9). A two-year follow-up study in China, which investigated the effects of E-learning environment use on visual function among 721 elementary and middle school students, determined that E-learning environment use time significantly affects visual acuity among students. The longer use of the E-learning environment significantly correlated with decreasing in horary visual acuity among students. The horary visual acuity changes were more significant in lower-grade students. The study implicated that some other causes of vision loss, in addition to the E-learning environment use after class, may be increased use of other digital devices and lack of exercise (10). Few studies showed that smartphone use is significantly associated with dry eye disease (DED) in children (11). Also, studies showed that the prevalence of DED is significantly higher among children in urban areas, as well as the rate of smartphone use (12). DESK study-1 in India, which investigated the prevalence of DES among schoolchildren before and during the COVID-19 pandemic, showed an increased prevalence of DES among children (50.23\%) during this pandemic due to the increased duration of online classes and increased digital screen time compared to some previous studies $(13,14)$. In this study, the significant risk factors for DES were the age of a child, digital screen time $>5 \mathrm{~h}$, and playing videogames on a smartphone for $>1 \mathrm{~h}$ per day, which, as authors suggest, is because of more hours of smartphone use and longer duration of online classes among older children during COVID-19 pandemic (13).

Eyesight, especially myopia, is still the most important issue related to digital screen time, near work, and outdoor activities. Related studies during the COVID-19 pandemic will be quite useful in investigating whether these factors are significant in a serious increase in the number of people with myopia. It is now well known that myopia is a serious public health and socio-economic problem, and high myopia is a risk factor for ocular complications that can lead to severe vision impairment and blindness. There is no doubt that getting a myopia diagnosis on time in children and preventing the progression to pathological high myopia is of crucial importance. Many studies performed before the COVID-19 pandemic highlighted that near work and outdoor time are important factors that can influence the onset and progression of myopia among children. However, more important is that these environmental factors are modifiable (15). Pärssinen $\mathrm{O}$ et al. in a 22-year-follow-up study, found that decreased outdoor time and increased near-work time in childhood are associated with adulthood high myopia (16). Some countries in East and Southeast Asia, where the epidemic of myopia is strongly connected with environmental factors, have implemented national myopia prevention program in schools that aims for more hours per day outdoors. Most of the studies based on the assessment of the efficacy of implementation of additional outdoor activities in schools were performed in those countries, which have been identified as "hot spots" when it comes to the myopia epidemic.

It is documented that higher levels of daily light exposure time reduce the myopia change in both non-myopic and myopic children, correlate with less axial eye growth, and can be used to slow down the onset of myopia, especially in younger children (17-25).

The association of near work and myopia is found to be more significant in children than in the older population, but more specific, longitudinal, and randomized controlled trials are needed to establish more consistent conclusions among experts. It is the same with digital screen time. A systematic review studies and meta-analysis indicates a link between near work and onset and progression of myopia. They also show that, when it comes to near work, the time that children spend reading is a significant factor for myopia in children, not the time they spend studying, using a com- 
puter, or watching TV. Also, the intensity more than the duration of near work is an important risk factor for myopia $(26,27)$. There is a growing number of studies that investigate the correlation between digital screen time, asthenopia, and eyesight. A previously mentioned study concluded that digital screen time $>5 \mathrm{~h}$ and playing videogames on a smartphone for $>1 \mathrm{~h}$ per day are significant risk factors for DES among schoolchildren in India (13). A strong correlation between digital screen time and myopia was estimated in more studies among schoolchildren. Studies in India estimated that the risk of myopia was 8 times higher among children with more than 2 hours/day of mobile and video game screen time compared to children with 0-2 hours/ day and 8 times higher in children with $>4 \mathrm{hr} /$ week of screen time compared to those with no screen time $(28,29)$. In Ireland, a relevant study determined that the incidence of myopia is significantly higher among school children, with more than $3 \mathrm{~h}$ /day of smartphone screen time compared to those who used smartphones less than 1 hour per day (30). Among the other digital devices, smartphone overuse is significantly positively associated with the incidence of visual impairment and digital eyestrain, and children are the most vulnerable group of the population $(13,31)$. Although the limitations of recent studies require further investigations, their results indicate a myogenic effect of increased digital screen time with special emphasis on younger children. Excessive use of digital devices also reduces outdoor time, which can also affect the onset and progression of myopia.

COVID-19 pandemic opened a significant need for new studies, clinical trials, and screening to better assess all direct and indirect effects of all known risk factors on ocular health and visual function. Those findings will be very helpful for future strategies and planning further public health measures for prevention and treatment of myopia and other consequent eye conditions, particularly among children, because of its potential to influence their learning, school performance, and thus their future. Anti-epidemic measures during the COVID-19 pandemic created the "ideal" conditions for all relevant risk factors that can compromise visual health in children. They led to increased indoor time, significant growth in digital screen time, excessive near work. What can the findings of current studies tell us?

Since the pandemic started in China, the first results came from their studies. In a large prospective cross-sectional study, which included 123535 children aged 6-8 years in China, researchers aimed to investigate the prevalence and progression of myopia during the COVID-19 home confinement. The prevalence of myopia increased 1.4 to 3 times in 2020 compared with the previous years (2015-2019), and the myopic shift was significant among younger children aged $6(-0.32$ D), $7(-0.28$ D), and $8(-0.29$ D) years (32). Preliminary results of the study among children in Argentina, 5-18 years of age, are similar. The mean annual progression of myopia was significantly higher during the period 2019-2020 than 2018-2019 and was less in older children (33). One smaller study included 115 myopic children in Alanya, aged 8-17 years, who have been followed up for at least three years before the pandemic. Myopia progression was statistically significant in 2020 compared to the previous three years and significantly less among children who spent $2 \mathrm{~h}$ /day outdoor or lived in detached houses. Digital screen time and the type of device were not found to have a significant influence on myopia progression in this study (2). Erdinest et al. published interesting research among 14 children who have been treated with $0.01 \%$ atropine solution for myopia control for two years ((March 2019 until March 2021). During the whole second year, children were home-schooled. The average spherical equivalent refraction (SER) and axial length (AL) increased significantly during the year of the lockdowns compared to pre-lockdowns year treatment (34). The large sample size cohort study as a part of The Myopia Screening Survey of Children and Teenagers in Schools, conducted in 46 primary and junior high schools in Hangzhou, China, started in early 2019, with examinations performed 6-month intervals thereafter, show a progression of myopia among the respondents but in a partially reversible manner. Myopic progression was reversed partially half a year after the lockdown, which can be explained, as they speculate, by accommodative spasms during the lockdown, which is caused by decreased indoor time, increased digital screen time, and limited indoor space. They also found that younger participants are more susceptible to myopic progression during a lockdown, which they explain by two possible hypotheses: younger children had more restricted indoor time during the lockdown and they may be more sensitive to lifestyle changes during the lockdown (35). A study in Spain investigated the impact of in-house quarantine during the COVID-19 pandemic on the vision of school-aged children. This cross-sectional study analyzed the results obtained during the "scholar campaign in favor of the visual health" carried out in 2019 and 2020 among the children aged 5-7 years. They came to similar conclusions (36).

\section{CONCLUSION}

It is a fact that the COVID-19 pandemic and the intensity of measures taken to suppress the spread of the pandemic caused drastic lifestyle changes that led 
to decreased outdoor time, increased digital screen time, especially among children. More than 1 billion children are affected by school closures due to the pandemic globally. No matter how long and to what extent online learning will continue, behavioral changes and dependence on digital devices may persist even after the COVID-19 pandemic. Facing the problem of the myopia epidemic worldwide and its consequences, eye health professionals invest a lot of effort in studies and research that will help to prevent myopia and reduce its progression. According to that, the COVID-19 pandemic is a reason for great concern. A very important conclusion of previous studies is that younger children are significantly sensitive to factors such as increased indoor, digital device time and increased near work compared to teenagers and adolescents, and they show significantly higher myopic shift and prevalence of DES when it comes to these risk factors. The sooner myopia develops, the greater is the risk for developing more serious eye conditions later in life, like retinal detachment, macular degeneration, and glaucoma. Therefore, it is of great importance to raise awareness among schools, children, parents, and relevant institutions and to work on productive collaboration among them. Prompt implementation of adequate public and school policies and eye care services globally, effective planning of public health measures for prevention and treatment of myopia must be part of the crucial measures in the future. The consequences of widespread acceptance of digital devices in all spheres of public life by affecting visual function also affect learning, school performance, and development of children, and thus their future.

\section{Acknowledgment}

None.

Conflict of Interests: The authors declare that there are no conflicts of interest related to this article.

Funding: None

\section{Licensing}

This work is licensed under a Creative Commons Attribution 4.0 International (CC BY 4.0) License.

\title{
Sažetak
}

\section{PREKOMERNA UPOTREBA DIGITALNIH UREĐAJA TOKOM COVID-19 PANDEMIJE I POREMEĆAJI VIDA KOD DECE: POSTOJI LI RIZIK ZA DUGOROČNE EFEKTE?}

\author{
Detanac A. Dzenana \\ Department of ophthalmology, General hospital Novi Pazar, Serbia
}

Globalno zatvaranje škola i kućni karantin zbog pandemije COVID-19 povećavaju vreme korišćenja digitalnih uređaja kao i ukupno vreme rada na blizinu, a smanjuju vreme boravka na otvorenom, posebno među školskom decom, što može uticati na pojavu astenopije, refraktivnih grešaka, smanjenja vidne oštrine i insuficijencije akomodacije. Stručnjaci veruju da oftalmolozi sada imaju posebnu priliku da apeluju na ovaj problem, da podignu svest o tome među roditeljima, decom i prosvetnim radnicima, pa i da utiču na nadležne organe u smislu razvijanja strategija koje će pomoći deci i studentima, kao i roditeljima i rele-

\section{REFERENCES}

1. Wong CW, Tsai A, Jonas JB, Ohno-Matsui K, Chen J, Ang M, et al. Digital screen time during the COVID-19 pandemic: risk for a further myopia boom? Am J Ophthalmol. 2020; 223: 333-7. doi: 10.1016/j.ajo.2020.07.034.

2. Aslan F, Sahinoglu-Keskek N. The effect of home education on myopia progression in children during the COVID-19 vantnim institucijama da se nose s ovim problemom i nakon pandemije. Brza implementacija odgovarajućih javnih i školskih programa i usluga za očuvanje zdravlja oka na globalnom nivou, kao i efektivna implementacija mera za prevenciju i lečenje miopije, moraju biti deo ključnijh mera za očuvanje javnog zdravlja u budućnosti. Posledice široko rasprostranjene upotrebe digitalnih uređaja u svim sferama javnog života utičući na vidne funkcije utiču takođe i na učenje, uspeh u školi i razvoj dece, a time i na njihovu budućnost.

Ključne reči: Covid-19, deca, prekomerna upotreba digitalnih uređaja, poremećaji vida.

pandemic [published online ahead of print, 2021 Jun 30]. Eye (Lond). 2021; 1-6. doi:10.1038/s41433-021-01655-2.

3. Wunsch K, Nigg C, Niessner C, Schmidt SCE, Oriwol D, Hanssen-Doose A, et al.The impact of COVID-19 on the interrelation of physical activity, screen time and health-related quality of life in children and adolescents in Germany: results of the Motorik-Modul Study. Children (Basel). 2021; 8(2): 98. doi:10.3390/children8020098. 
4. Nobari H, Fashi M, Eskandari A, Villafaina S, Murillo-Garcia Á, Pérez-Gómez J. Effect of COVID-19 on health-related quality of life in adolescents and children: a systematic review. Int J Environ Res Public Health. 2021; 18(9): 4563. doi:10.3390/ijerph18094563.

5. Holden BA, Fricke TR, Wilson DA, Jong M, Naidoo KS, Sankaridurg P, et al. Global prevalence of myopia and high myopia and temporal trends from 2000 through 2050. Ophthalmology. 2016; 123(5): 1036-42. doi: 10.1016/j.ophtha.2016.01.006.

6. Bourne RR, Stevens GA, White RA, Smith LA, Flaxman SR, Price H, et al. Causes of vision loss worldwide, 19902010: a systematic analysis. The Lancet Global Health. 2013; 1(6): 339-49. doi:10.1016/S2214-109X(13)70113-X.

7. Naidoo KS, Fricke TR, Frick KD, Jong M, Naduvilath TJ, Resnikoff S. Potential lost productivity resulting from the global burden of myopia: systematic review, meta-analysis, and modeling. Ophthalmology. 2019; 126(3): 338-46. doi: 10.1016/j.ophtha.2018.10.029.

8. Wong TY, Ferreira A, Hughes R, Carter G, Mitchell P. Epidemiology and disease burden of pathologic myopia and myopic choroidal neovascularization: an evidence-based systematic review. Am J Ophthalmol. 2014; 157(1): 9-25. doi: 10.1016/j.ajo.2013.08.010

9. Kozeis N. Impact of computer use on children's vision. Hippokratia. 2009; 13(4): 230-1.

10. Zhang Z, Xu G, Gao J, Wang L, Zhu Y, Li Z, et al. Effects of e-learning environment use on visual function of elementary and middle school students: a two-year assessment-experience from China. Int J Environ Res Public Health. 2020; 17(5): 1560. doi: 10.3390/ijerph17051560.

11. Moon JH, Lee MY, Moon NJ. Association between video display terminal use and dry eye disease in school children. J Pediatr Ophthalmol Strabismus. 2014; 51(2): 87-92. doi: 10.3928/01913913-20140128-01.

12. Moon JH, Kim KW, Moon NJ. Smartphone use is a risk factor for pediatric dry eye disease according to region and age: a case-control study. BMC Ophthalmol. 2016; 16(1): 188. doi: 10.1186/s12886-016-0364-4.

13. Mohan A, Sen P, Shah C, Jain E, Jain S. Prevalence and risk factor assessment of digital eye strain among children using online e-learning during the COVID-19 pandemic: Digital eye strain among kids (DESK study-1). Indian J Ophthalmol. 2021; 69(1): 140-4. doi: 10.4103/ijo.IJO_2535_20.

14. Vilela MA, Pellanda LC, Fassa AG, Castagno VD. Prevalence of asthenopia in children: A systematic review with meta-analysis. J Pediatr Brazil. 2015; 91: 320-5. doi. org/10.1016/j.jped.2014.10.008.

15. Ramamurthy D, Lin Chua SY, Saw SM. A review of environmental risk factors for myopia during early life, childhood and adolescence. Clin Exp Optom. 2015; 98(6): 497-506. doi: $10.1111 /$ cxo. 12346 .

16. Parssinen O, Kauppinen M. Risk factors for high myopia: a 22-year follow-up study from childhood to adulthood. Acta Ophthalmologica. 2018; 97(5): 510-8. doi:10.1111/ aos.13964.

17. Wu PC, Chen CT, Lin KK, Sun CC, Kuo CN, Huang $\mathrm{HM}$, et al. Myopia prevention and outdoor light intensity in a school-based cluster randomized trial. Ophthalmology. 2018; 125(8): 1239-50. doi: 10.1016/j.ophtha.2017.12.011.
18. Read SA, Collins MJ, Vincent SJ. Light exposure and eye growth in childhood. Invest Ophthalmol Vis Sci. 2015; 56(11): 6779-87. doi: 10.1167/iovs.14-15978.

19. Morgan IG, He M, Rose KA. Epidemic of pathologic myopia: what can laboratory studies and epidemiology tell us? Retina. 2017; 37(5): 989-97. doi: 10.1097/ IAE.0000000000001272.

20. Rose KA, Morgan IG, Ip J, Huynh S, Smith W, Mitchell P. Outdoor activity reduces the prevalence of myopia in children. Ophthalmology. 2008; 115: 1279-85. doi.org/10.1016/j. ophtha.2007.12.019.

21. He M, Xiang F, Zeng Y, Mai J, Chen Q, Zhang J, et al. Effect of time spent outdoors at school on the development of myopia among children in China: a randomized clinical trial. JAMA. 2015; 314(11): 1142-8. doi: 10.1001/jama.2015.

22. Xiong S, Sankaridurg P, Naduvilath T, Zang J, Zou H, Zhu Jet al. Time spent in outdoor activities in relation to myopia prevention and control: a meta-analysis and systematic review. Acta Ophthalmol. 2017; 95(6): 551-66. doi:10.1111/aos.13403.

23. French AN, Morgan IG, Mitchell P, Rose KA. Risk factors for incident myopia in Australian schoolchildren: the Sydney adolescent vascular and eye study. Ophthalmology. 2013; 120(10): 2100-8. doi: 10.1016/j.ophtha.2013.02.035.

24. Guggenheim JA, Northstone K, McMahon G, Ness AR, Deere K, Mattocks C, et al. Time outdoors and physical activity as predictors of incident myopia in childhood: a prospective cohort study. Invest Ophthalmol Vis Sci. 2012; 53(6): 2856-65. doi:10.1167/iovs.11-9091.

25. Shah RL, Huang Y, Guggenheim JA, Williams C. Time outdoors at specific ages during early childhood and the risk of incident myopia. Invest Ophthalmol Vis Sci. 2017; 58(2): 115866. doi:10.1167/iovs. 16-20894.

26. Huang HM, Chang DST, Wu PC. The association between Near Work activities and myopia in children - a systematic review and meta-analysis. PLoS One. 10(10): e0140419. doi: 10.1371/journal.pone.0140419.

27. Ip JM, Saw SM, Rose KA, Morgan IG, Kifley A, Wang $\mathrm{JJ}$, et al. Role of near work in myopia: findings in a sample of Australian school children. Invest Ophthalmol Vis Sci. 2008; 49(7): 2903-10. doi: 10.1167/iovs.07-0804.

28. Singh NK, James RM, Yadav A, Kumar R, Asthana $\mathrm{S}$, Labani S. Prevalence of myopia and associated risk factors in schoolchildren in North India. Optom Vis Sci. 2019; 96(3): 200-5. doi: 10.1097/OPX.0000000000001344.

29. Saxena R, Vashist P, Tandon R, Pandey RM, Bhardawaj A, Menon V, et al. Prevalence of myopia and its risk factors in urban school children in Delhi: the North India Myopia Study (NIM Study). PLoS One. 2015; 10(2): e0117349. doi: 10.1371/ journal.pone.0117349.

30. McCrann S, Loughman J, Butler JS, Paudel N, Flitcroft DI. Smartphone use as a possible risk factor for myopia. Clin Exp Optom. 2021; 104(1): 35-41. doi:10.1111/cxo.13092.

31. Wang J, Li M, Zhu D, Cao Y. Smartphone overuse and visual impairment in children and young adults: systematic review and meta-Analysis. J Med Internet Res. 2020; 22(12): e21923. doi: 10.2196/21923.

32. Wang J, Li Y, Musch DC, Musch DC, Wei N, Qi $\mathrm{X}$, et al. Progression of myopia in school-aged children after COVID-19 home confinement. JAMA Ophthalmol. 2021; 139(3): 293-300. doi: 10.1001/jamaophthalmol.2020.6239. 
33. Piccoti C, Sanchez V, Irigaray LF, Morgan IG, Iribarren R. Myopia progression in children during COVID-19 home confinement in Argentina. Preprint at http://dx.doi.org/10.2139/ ssrn. 3781660 .

34. Erdinest N, London N, Levinger N, Lavy I, Pras E, Morad Y. Decreased effectiveness of $0.01 \%$ atropine treatment for myopia control during prolonged COVID-19 lockdowns. Cont Lens Anterior Eye. 2021; 3: 101475. doi: 10.1016/j. clae.2021.101475.

\section{Correspondence to/Autor za korespondenciju}

Dzenana Detanac

Department of ophthalmology, General hospital Novi Pazar

Generala Zivkovica bb, 36300 Novi Pazar, Serbia

Phone: +381642128020

Email: dzenana.detanac@gmail.com
35. Chang P, Zhang B, Lin L, Chen R, Chen S, Zhao Y, et al. Comparison of myopic progression before, during, and after COVID-19 lockdown. [published online ahead of print, 2021 Mar 23]. Ophthalmology. 2021; S0161-6420(21)00234-7. doi:10.1016/j.ophtha.2021.03.029.

36. Alvarez-Peregrina C, Martinez-Perez C, Villa-Collar C, Andreu-Vazquez C, Ruiz-Pomeda A, Sanchez-Tena MA. Impact of COVID-19 home confinement in children's refractive errors. Int J Environ Res Public Health. 2021; 18(10): 5347. doi:10.3390/ijerph18105347. 